УДК 336.01

JEL Classification: G17

О. С. БЈЛОУСОВА,

кандидат економічних наук,

стариий науковий співробітник відділу державних фінансів, ДУ "Інститут економіки та прогнозування НАН України",

\title{
Інвестиційний потенціал економіки України та країн СС
}

У статті розкрито сутність інвестиційного потенціалу економіки, ресурсного i витратного підходів до його оцінювання. Проаналізовано статистичні показники, щи відображають інвестиційний потенціал в крайнах ЄС і Украйні (рівень нагромаджсення основного капіталу сектором нефінансових корпорацій, частка прибутку сектору нефінансових корпорацій). Розроблено пропозицій щодо удосконалення системи показників статистики інвестицій.

Ключові слова: інвестицій, інвестищійний тренд, інвестиџійний потенціал, ризик інвестування, прибуток.

Постановка проблеми. Формування та реалізація інвестиційного потенціалу економіки - це процеси, які суттєво впливають на економічний розвиток країни і забезпечують прискорення його темпів на довгострокову перспективу, особливо якщо вони мають інноваційний характер. Успішність реалізації інвестиційного потенціалу у стратегічних сферах (де реалізуються національні пріоритети) позитивно позначається на макроекономічній стабільності та економічному розвитку країни.

Однак інвестиційні тренди, які склалися в останні роки у багатьох країнах світу, свідчать про існування проблем не лише формування інвестиційного потенціалу, а й ефективності його використання на внутрішніх і зовнішніх інвестиційних ринках. Підтвердженням цього є збільшення у 2015 р. глобальних потоків прямих іноземних інвестицій на 40\%, до 1,8 трлн дол., що не привело до еквівалентного зростання виробничого потенціалу, зокрема у сфері “'зеленої економіки", відновлення сталого розвитку у країнах, які отримали інвестищії [1].

Тенденції до зниження ефективності реалізації інвестиційного потенціалу, збільшення дефіциту інвестиційних ресурсів у вітчизняних підприємств актуалізують дослідження питань, пов'язаних із оцінюванням інвестиційних процесів, з метою формування достовірної інформаційної бази для управління інвестиційною діяльністю, а також прогнозування темпів економічного розвитку на середньострокову перспективу. Забезпечення належного інвестиційного потенціалу має важливе значення для модернізації виробництва на інноваційній основі.

Аналіз останніх досліджень і публікацій. Проблеми оцінювання сучасних інвестиційних процесів, державної підтримки формування та реалізації інвестиційного потенціалу досліджувалися у роботах Ю. Бажала, В. Гейця, А. Даниленка, І. Сгорова, І. Крючкової, І. Луніної, І. Одотюка, С. Онишко, К. Перес, О. Саліхової та інших [2-6]. І. Бережна, М. Вознюк, В. Гавриш, Д. Горіцин, О. Гудзь, Л. Гулько, С. Дідух, Т. Драганова, Д. Дресвянніков, Г. Дурицька, І. Жувагіна, С. Заїка, В. Здреник, 3. Калініченко, О. Колтунович, М. Чорна, Т. Шабатура, Г. Шамота, О. Щербатюк та інші визначають сутність інвестиційного потенціалу та методичне забезпечення його оцінювання [7-20]. Більшість доробок вітчизняних вчених грунтуються на ресурсному підході. Проте недостатньо уваги приділено витратному підходу, який застосовується у країнах ЄС. Запропоновані у науковій літературі методики оцінювання інвестиційного потенціалу, зокрема склад показників та інформаційна база для їх розрахунку (дані аналітичного і синтетичного бухгалтерсыкого, управлінсыкого, податкового обліку та фінансової звітності), можуть використовуватися лише для аналізу окремих підприємств. Потребують дослідження проблеми методологічного і методичного забезпечення оцінювання інвестиційного потенціалу національної економіки.

Метою статті $€$ дослідження сутності та підходів до оцінювання інвестиційного потенціалу економіки, обчислення інвестиційного потенціалу реального сектору

(C) О. С. Білоусова, 2017 
економіки України за витратним підходом, проведення порівняльного аналізу 3 потенціалом країн $€ C$, а також розроблення пропозицій щодо удосконалення системи показників статистики інвестицій в Україні.

Виклад основного матеріалу. Інвестиційний потенціал характеризує здатність економіки фінансувати процеси, пов'язані з генеруванням інновацій, створенням та модернізацією основних виробничих фондів, нематеріальних активів; розвитку освітнього, наукового та інформаційного потенціалу; відновленням, підтримкою та примноженням національного багатства.

Інвестиційний потенціал економіки досліджується за різними підходами.

О. Щербатюк інвестиційний потенціал підприємства визначає як комплекс інвестищійних ресурсів у поєднанні з можливостями, засобами та умовами їхнього залучення і використання в інвестиційній діяльності підприємства [20]. I. Бережною інвестиційний потенціал розглядається як запас наявних можливостей інвестиційних ресурсів певного таксономічного рівня, потужність потоку яких щодо продукування інвестиційних доходів-ризиків зумовлена спроможностями інституційного середовища забезпечити безперервність та інтенсивність протікання інвестиційного процесу [7]. Д. Дресвянніков трактує цей термін як сукупну можливість власних і залучених економічних ресурсів забезпечувати при наявності сприятливого інвестиційного клімату інвестиційну діяльність підприємства з метою і масштабах, визначених економічною політикою країни та стратегією розвитку підприємства [12]. С. Дідух визначає інвестиційний потенціал підприємства як здатність реалізувати сукупність інвестиційних можливостей щодо генерування додаткових потоків капіталу завдяки мобілізаціі наявних ресурсів 3 метою підвищення ефективності діяльності підприємства [11]. С. Заїка інвестиційним потенціалом визнає сукупність прихованих інвестиційних ресурсів, джерел, можливостей, засобів, запасів, які під впливом зовнішніх або внутрішніх факторів інвестиційного середовища формуються і починають взаємодіяти для вирішення поставлених стратегічних завдань в результаті інвестиційної діяльності підприємства [13]. А. Жулавський, В. Гордієнко, О. Самофалова трактують його як сукупність інвестиційних ресурсів в поєднанні з можливостями, засобами і умовами їх залучення і використання у інвестиційній діяльності підприємства [21]. В. Гавриш, Л. Гулько, Т. Драганова зазначають, що формування інвестиційного потенціалу відбувається в результаті поступового свідомого чи несвідомого накопичення інвестиційних можливостей, які не можуть бути реалізовані підприємством миттєво. Інвестиційні можливості можуть, зокрема, бути створені та використані підприємством шляхом мобілізації внутрішніх інвестицийних ресурсів [9].

Вищенаведені визначення терміна “інвестиційний потенціал” відображають ресурсний підхід, оскільки за основу взято фінансові та інші ресурси підприємства, наявний інструментарій управління ними для забезпечення інвестиційного процесу.

М. Чорна, І. Жувагіна, Д. Горіцин пропонують інший підхід, згідно 3 яким інвестиційний потенціал підприємства - це комплексна система, шо становить сукупність окремих підсистем (інвестиційно-фінансова та управлінська) [17]. Т. Шабатура зазначає, що формування інвестиційного потенціалу підприємства для всіх учасників інвестиційного процесу виступає якісним критерієм оцінювання підприємства як товару, зростання якого свідчить про адекватність ведення економічної діяльності підприємства принципам соціально орієнтованої концепції, що, у свою чергу, сприяє вирішенню економічних проблем, які виникають між ними [18]. Ці визначення відображають ресурсно-управлінський підхід, оскільки підприємство розглядається як сформована система, спроможна здійснювати інвестиційну діяльність та має інвестиційний потенціал для розвитку.

На нашу думку, визначення терміна "інвестиційний потенціал економіки" має базуватися на положеннях витратного підходу. Згідно з ним інвестиційний потенціал це здатність до фінансового забезпечення висхідного інвестиційного тренду шляхом нагромадження основного капіталу та збільшення доходності і прибутковості від його генерування у поточному та середньостроковому періодах.

Методичне забезпечення оцінювання інвестиційного потенціалу, наведене у науковій літературі, також може бути згруповано за ресурсним та витратним підходами В. Скриль, О. Дяченко для оцінювання інвестиційного потенціалу підприємства про- 
понують застосовувати такі фінансові коефіцієнти та співвідношення: показники ліквідності (ліквідність активів); показники оборотності (оборотність активів); показники структури капіталу (фінансова стійкість) та показники прибу тковості (прибутковість капіталу) [22]. М. Вознюк і Г. Дурицька пропонують такі показники: 1) обсяг накопичених власних і залучених ресурсів (фінансових, матеріальних і нематеріальних); 2) здатність до ефективного інвестування; та інші [8]. Оцінювання за цими показниками здійснюється за ресурсним підходом.

На підставі узагальнення наведених показників та визначення терміна “інвестиційний потенціал" за ресурсним підходом пропонується уточнити перелік показників оцінювання інвестишійного потеншіалу, доповнивши його такими, як: обсяг чистого прибутку, амортизації, інвестиційної нерухомості (сформованих у минулих роках та поточному періоді); сума тимчасово залучених і позикових ресурсів для цілей інвестування; обсяг ресурсів від державної підтримки (зокрема, від податкових пільг).

Д. Лейтне, Т. Смокова, інші зарубіжні вчені та експерти Євростату застосовують витратний підхід до оцінювання рівня інвестування підприємств [23-24]. За витратним підходом аналізується динаміка інвестиційної ставки (рівня нагромадження основного капіталу підприємствами). За методологією Євростату інвестиційна ставка визначається діленням обсягу валового нагромадження основного капіталу (The European System of National and Regional Accounts (ESA 2010), код: Р.51g) на обсяг валової доданої вартості ((ESA 2010), код: Blg) та відображає частку інвестицій підприємств в основний капітал (будівлі, обладнання тощо) в обсязі створеної в процесі виробництва доданої вартості (табл. 1).

Табличя 1

Рівень нагромадження основного капіталу сектором нефінансових корпорацій (інвестиційна ставка) * \% від доданої вартості

\begin{tabular}{|c|c|c|c|c|c|c|c|c|c|c|c|c|}
\hline \multirow{2}{*}{$\begin{array}{c}\text { Країна та } \\
\text { група країн }\end{array}$} & \multicolumn{4}{|c|}{2014} & \multicolumn{4}{|c|}{2015} & \multicolumn{4}{|c|}{2016} \\
\hline & I KB & II кв & III кB & $V_{\text {кв }}$ & І І кв & II KB & III кB & IV KB & I KB & I KB & III кв & $\mathrm{V}_{\mathrm{KB}}$ \\
\hline & 1,29 & 21,99 & 21,24 & 22,35 & 21,39 & 22,45 & 21,14 & 22,30 & 21,69 & 22,81 & 21,32 & 23,94 \\
\hline СС (28 країн) & 20,92 & 21,98 & 21,42 & 22,59 & 21,27 & 22,37 & 21,46 & 22,54 & 21,32 & 22,7 & 21,46 & \\
\hline Бельгія & 22,92 & 24,16 & 26,76 & 27,98 & 26,26 & 23,97 & 24,05 & 27,87 & 23,34 & 24,65 & 24,57 & \\
\hline $\begin{array}{l}\text { Чесb } \\
\text { Рес }\end{array}$ & 2793 & 2724 & 2881 & 3030 & 2790 & 28,23 & 2900 & 2877 & 2678 & 2644 & 28.33 & 3066 \\
\hline Данія & 21,47 & 20,77 & 20,78 & 21,28 & 21,00 & 21,34 & 20,83 & 21,68 & 23,08 & 22,25 & 22,30 & 22,60 \\
\hline Нiмец & 19,08 & 20,41 & 19,47 & 20,49 & 18,82 & 20,09 & 19,30 & 20,42 & 19,01 & 20,17 & 19,33 & 20,17 \\
\hline Естон & 22,43 & 22,48 & 21,07 & 28,73 & 19,91 & 21,59 & 19,26 & 26,33 & 19,87 & 22,16 & 15,85 & 21,93 \\
\hline Ірлацдія & 25,35 & 22,39 & 24,2 & 25,64 & 20,9 & 26,76 & 26,97 & 21,84 & 19,62 & 31,19 & \begin{tabular}{|l|}
20,77 \\
\end{tabular} & \\
\hline Греція & 17,44 & 19,34 & 13,01 & 11,64 & 17,37 & 15,21 & 14,48 & 13,29 & 20,00 & 20,92 & \begin{tabular}{|l|}
15,67 \\
\end{tabular} & \\
\hline Iспанія & 25,84 & 25,62 & 25,91 & 25,89 & 26,59 & 28,18 & 24,59 & 25,27 & 28,51 & 28,15 & 27,10 & 26,29 \\
\hline Франція & 22,41 & 22,86 & 22,02 & 23,84 & 22,17 & 22,98 & 22,01 & 24,23 & 22,91 & 23,64 & 22,51 & 24,53 \\
\hline Хорват & 27,16 & 27,00 & 25,60 & 26,30 & 28,03 & 28,39 & 26,79 & 28,12 & 28,57 & 29,53 & 26,81 & \\
\hline Італія & 20,18 & 20,07 & 18,74 & 19,36 & 20,61 & 20,1 & 18,61 & 18,82 & 20,31 & 20,04 & 18,7 & 19,95 \\
\hline Нідерланди & 15,46 & 16,46 & 14,65 & 18,88 & 16,23 & 17,45 & 14,96 & 20,43 & 17,02 & 17,65 & 15,46 & 18,45 \\
\hline Австрія & 23,8 & 26,1 & 26,12 & 26,35 & 23,55 & 26,13 & 25,85 & 26,22 & 23,58 & 27,32 & 26,60 & 26,36 \\
\hline Польща & 15,31 & 20,55 & 20,26 & 30,57 & 15,82 & 20,9 & 21,26 & 30,51 & 14,71 & 19,34 & \begin{tabular}{|l|}
19,38 \\
\end{tabular} & \\
\hline Португалія & 20,66 & 22,82 & 20,13 & 20,00 & 21,46 & 21,84 & 20,02 & 18,17 & 21,46 & 21,69 & 20,14 & 20,19 \\
\hline Румунія & 20,85 & 28,59 & 35,78 & 22,75 & 22,25 & 28,14 & 34,56 & 23,32 & 21,84 & 28,14 & 33,55 & \\
\hline Фінляндія & 18,19 & 19,46 & 21,53 & 20,33 & 18,90 & 20,26 & 21,67 & 20,97 & 18,8 & 21,33 & 21,72 & 22,55 \\
\hline Швеція & 26,31 & 27,08 & 25,38 & 28,07 & 27,38 & 28,39 & 25,62 & 28,77 & 27,59 & 29,65 & 26,37 & 28,63 \\
\hline $\begin{array}{l}\text { Велил } \\
\text { Бритг }\end{array}$ & 16,00 & 16,93 & 16,81 & 17,65 & 17,41 & 17,05 & 17,57 & 17,30 & 16,28 & 16,72 & 16,6 & 17,11 \\
\hline Hopв & 19,63 & 22,65 & 23,12 & 21,90 & 20,60 & 22,34 & 20,75 & 21,26 & 20,31 & 21,26 & 21,9 & 20,64 \\
\hline 1 & & & & 21,82 & & & & 19,63 & & & & \\
\hline
\end{tabular}

Джерело: дані Свростату [24], для України розраховано автором за даними Державної службои статистики України. 
У країнах СС-19 за період 2014-2016рр. значення інвестиційної ставки коливалося в межах від 21,1\% до 23,9\%. У IV кв. 2016 р. спостерігалося зростання інвестиційної ставки порівняно $з$ попереднім роком у Австрії, Данії, Іспанії, Італії, Португалії, Фінляндії, Франції, Чеській Республіці. У Чеській Республіці у 2014-2016 рр. спостерігалося поряд із сезонними коливаннями, суттєве зростання інвестиційної ставки до $30,7 \%$. Для оцінювання застосовується і середньорічне значення цього показника - у СС-19 воно становило: $21,7 \%$ у 2014 р., 21,8\% у 2015 р. та $22,4 \%$ у 2016 р. У 2016 р. порівняно 3 2014 р. відбулося суттєве скорочення рівня бізнес-інвестицій в Естонії, на 3,7 в. п. [24].

Розрахунки інвестицгійного потенціалу економіки України, проведені за наведеною вище методологією Свростату (витратний підхід), показали, що у 2014 р. інвестиційна ставка становила $21,82 \%$, що майже відповідає рівню країн СС-19. Проте у 2015 р. в Україні, на відміну від країн ЄС-19, їі рівень зменшився на 2,19 в. п. і становив 19,63\%.

Додатковим показником, який застосовується для оцінювання інвестиційного потенціалу, є прибутковість підприємств (таб̆л. 2). Частка прибутку підприємства, за підходом Свростату, визначається шляхом ділення валового прибутку, змішаного доходу ((ESA 2010), код: В2g-B3g) на обсяг валової доданої вартості ((ESA 2010), код: $\mathrm{B} 1 \mathrm{~g})$. Цей показник відображає інвестищійний потенціал як результат нагромадження основного капіталу у попередніх періодах. Це також може свідчити про успішність інвестиційного процесу та наявність власних ресурсів підприємств для фінансування інвестиційних проектів.

Таблиця 2

Частка прибутку сектору нефінансових корпорацій“", \% від доданої вартості

\begin{tabular}{|c|c|c|c|c|c|c|c|c|c|c|c|c|}
\hline \multirow{2}{*}{$\begin{array}{c}\text { Країна та } \\
\text { група країн }\end{array}$} & \multicolumn{4}{|c|}{2014} & \multicolumn{4}{|c|}{2015} & \multicolumn{4}{|c|}{2016} \\
\hline & I KB & II KB & III KB & IV KB & I KB & II кв & III кв & IV кв & I KB & II кB & III кB & IV кв \\
\hline $\begin{array}{l}\text { Зона євро } \\
\text { (19 країн) }\end{array}$ & 2,30 & 37,78 & 41,61 & 38,22 & 43,02 & 38,68 & 42,16 & 39,09 & 42,28 & 39,32 & 42,12 & 39,26 \\
\hline СС (28 країн) & 0,05 & 37,70 & 40,98 & 39,13 & 40,18 & 38,24 & 40,95 & 39,48 & 39,98 & 38,57 & 40,73 & \\
\hline Бельгія & 2,30 & 39,29 & 45,09 & 35,89 & 43,22 & 40,31 & 46,55 & 37,93 & 44,12 & 41,86 & 47,46 & \\
\hline $\begin{array}{l}\text { Чеська } \\
\text { Респуу }\end{array}$ & 9,42 & 51,42 & 51,57 & 52,23 & 50,71 & 51,57 & 51,84 & 51,28 & 49,11 & 52,19 & 49,56 & 49,73 \\
\hline Данія & 39,39 & 38,27 & 42,74 & 43,82 & 40,83 & 39,30 & 42,71 & 42,65 & 37,03 & 36,55 & 41,72 & 41,80 \\
\hline Німеччиина & 44,38 & 40,76 & 43,12 & 38,28 & 44,46 & 40,92 & 42,99 & 38,31 & 43,86 & 42,02 & 42,66 & 37,97 \\
\hline Естонія & 47,65 & 48,22 & 49,20 & 47,21 & 43,13 & 44,58 & 44,68 & 42,81 & 39,34 & 41,92 & 43,28 & 42,57 \\
\hline Ірландія & 56,17 & 58,42 & 61,28 & 60,56 & 70,30 & 70,13 & 70,14 & 72,31 & 69,65 & 66,90 & 69,95 & \\
\hline Греція & 59,73 & 55,51 & 61,43 & 40,52 & 60,08 & 58,22 & 60,89 & 37,78 & 55,91 & 53,99 & 55,40 & \\
\hline Іспанія & 41,30 & 41,94 & 40,86 & 46,32 & 41,05 & 42,27 & 41,14 & 45,79 & 40,96 & 43,11 & 41,27 & 46,46 \\
\hline Франція & 34,85 & 26,76 & 31,02 & \begin{tabular}{|l|}
28,81 \\
\end{tabular} & 36,17 & 27,90 & 31,64 & 30,05 & 36,34 & 29,24 & 31,91 & 29,4 \\
\hline Хорватія & 25,29 & 27,64 & 36,30 & 29,78 & 24,00 & 26,67 & 35,55 & 29,02 & 23,74 & 26,47 & 36,21 & \\
\hline Італія & 43,19 & 39,67 & 46,35 & 35,95 & 42,51 & 39,26 & 46,60 & 36,18 & 43,27 & 40,29 & 47,53 & 37,12 \\
\hline Нідерлан & 4,24 & 33,04 & 44,77 & 42,12 & 44,14 & 34,48 & 45,93 & 42,26 & 43,78 & 34,50 & 45,26 & 41,59 \\
\hline Австрія & 42,53 & 38,01 & 42,59 & 42,53 & 41,76 & 38,57 & 42,97 & 41,85 & 40,94 & 37,96 & 42,33 & 41,65 \\
\hline Польща & 50,61 & 46,97 & 45,98 & 56,27 & 51,35 & 50,11 & 46,17 & 58,06 & 51,64 & 49,70 & 46,37 & \\
\hline Португалія & 43,52 & 43,20 & 43,27 & 37,53 & 43,53 & 42,28 & 43,13 & 37,85 & 43,64 & 42,17 & 43,46 & 37,06 \\
\hline Румунія & 53,52 & 55,84 & 55,21 & 61,35 & 54,26 & 53,69 & 56,39 & 62,32 & 44,86 & 50,55 & 57,04 & \\
\hline Фінляндія & 32,97 & 36,77 & 38,10 & 34,01 & 34,19 & 35,39 & 38,25 & 33,81 & 33,54 & 34,54 & 38,24 & 33,59 \\
\hline Швеція & 37,56 & 39,63 & 38,66 & 45,14 & 38,42 & 40,75 & 39,15 & 45,72 & 38,17 & 41,07 & 38,19 & 45,37 \\
\hline $\begin{array}{l}\text { Велика } \\
\text { Британія }\end{array}$ & 35,54 & 36,71 & 31,72 & 39,98 & 35,88 & 37,25 & 32,72 & 40,26 & 35,24 & 37,44 & 30,84 & 39,36 \\
\hline Норвегія & 32,48 & 36,14 & 38,65 & 37,72 & 31,99 & 35,76 & 37,08 & 37,38 & 31,99 & 35,35 & 36,52 & 37,67 \\
\hline Україна & $\ldots$ & $\ldots$ & $\ldots$ & 38,55 & ... & $\ldots$ & $\ldots$ & 47,26 & * & $\ldots$ & & 列 \\
\hline
\end{tabular}

Примітка: * - нескориговані дані (без сезонних та календарних корегувань).

Джерело: дані Свростату [24]. Для України розраховано автором за даними Державної служби статистики України. 
У країнах ЄС-19 за період 2014-2016 рр. частка прибутку підприємств коливалась від $37 \%$ до 41\%. Індикатор прибутковості (сезонно і календарно скорегований) упродовж IV кв. 2013 р. - IV кв. 2016 р. був досить постійним і становив близыко $40 \%$ [25]. У 2016 р. середньорічний показник збільшився до 40,7\% або на 0,8 в. п. У IV кв. 2016 р. збільшення рівня прибутковості (порівняно з IV кв. 2015 р.) спостерігалося лише в Іспанії, Італії та Норвегії. Найменші частки прибутку серед країн-членів ЄС були зафіксовані в Хорватії (середньорічні показники - 29,8\% та 28,8\% у 2014 та 2015 рр.) і Франції (середньорічні показники - 30,4\%; 31,4\% та 31,7\% у 2014, 2015 , 2016 рр., відповідно).

В Україні частка прибутку у доданій вартості (розрахована на наведеною вище методологією) у 2014 р. становила $38,55 \%$ та у 2015 р. збільшилася на 8,71 в. п. до $47,26 \%$. Порівняння цього показника з інвестиційною ставкою дає підстави для висновку, що збільшення прибутковості (власних ресурсів підприємств) на тлі значних інвестиційних потреб не призводить до збільшення інвестицій та реалізації інвестиційного потенціалу в Україні.

На нашу думку, для оцінювання інвестиційного потенціалу України доцільно застосовувати не лише ресурсний підхід, що відображає акумульовані підприємствами ресурси для операційної, фінансової та інвестиційної діяльності, а й витратний підхід, що відображає інвестиційний тренд та його вплив на рівень прибутковості. За нашими оцінками, інвестиційний потенціал економіки України за період 2013-2015 рр. зменшився 3606 млрд грн у 2013 р. до 590 млрд грн у 2014 р. і до приблизно 565 млрд грн y 2015 p.

Про доцільність застосування витратного підходу до визначення та оцінювання інвестиційного потенціалу економіки також свідчать результати досліджень поведінки іноземних підприсмств щодо їх участі в інвестиційних процесах, фінансуванні інновацій, проведені зарубіжними дослідниками [4; 26-29], зокрема:

- д достатньо високий рівень операційного прибутку та загальні чисті збитки всієї господарської діяльності підприємств у будь-яких країнах стримують інвестування, зокрема в інноваційні проекти, які на початкових стадіях не мають високого рівня прибутковості і у більшості є ризикованими;

- підприємства, враховуючи наслідки кризи 2008-2009 pp., швидше вкладають кошти в надійні проекти розвитку енергетики, інші прибуткові підприємства, ніж у наукові дослідження та інноваціі;

- призупинення або уповільнення темпів фінансування інвестиційних проектів відбувається під впливом політичних (включаючи невизначеність щодо Brexit) та макроекономічних ризиків.

Нестабільність та ризикованість інвестиційних витрат впливає на інвестиційні тренди та тривалість циклів ділової активності підприємств. Інвестування підприсмств у технологічні інновації виробництва та виробничої інфраструктури (зв'язку, транспорту тощо) сприяють утворенню мультиплікаційного ефекту та його поширенню на всю галузь або економіку.

Технологічні інновації, як і будь-які інші, створюють ризики для підприємств, які вчасно не сформували інвестиційний потенціал. Експертами міжнародної аудиторської та консалтингової фірми BDO було проведено опитування 500 великих та середніх підприємств різних видів економічної діяльності у 44 країнах світу щодо ризиків, які імовірно виникатимуть у короткостроковому і середньостроковому періодах та впливатимуть на їх фінансовий стан [30]. Основними ризиками було визначено: посилення конкуренції ( $40 \%$ респондентів), зокрема через запровадження конкурентами інновацій $(23 \%)$; зменшення попиту (33\%); політична та/або регуляторна невизначеність (32\%); підвищення відсоткових ставок $(26 \%)$; валютна волатильність $(25 \%)$; податковий ризик $(10 \%)$. Це свідчить про необхідність підвищення попиту на інвестиційні проекти, прибутковість реалізації яких перевищуватиме імовірний рівень ризику інвестиційних втрат.

Для удосконалення формування системи показників статистики інвестицій пропонується запровадити в У країні такі показники: рівень нагромадження основного капіталу (інвестиційну ставку) та рівень прибутковості (\% від доданої вартості); рентабельність інвестиційної діяльності підприємств. Своєчасність, достовірність 
та порівнянність оцінок інвестиційного потенщіалу забезпечуватиметься застосуванням статистичних даних системи національних рахунків. Це дозволить зіставляти національну статистичну інформацію про рівень інвестицій з міжнародною.

\section{Висновки}

1. Формування та реалізація інвестиційного потенціалу характеризують здатність економіки фінансувати процеси, пов'язані з генеруванням інновацій, створенням та модернізацією основних виробничих фондів, нематеріальних активів; розвитком освітнього, наукового та інформаційного потенціалу; відновленням, підтримкою та примноженням національного багатства.

2. Інвестиційний потенціал економіки (за витратним підходом) визначено як здатність реального сектору економіки до фінансового забезпечення висхідного інвестиційного тренду шляхом нагромадження основного капіталу та збільшення доходності і прибутковості від його генерування у поточному та середньостроковому періодах.

3. Рівень нагромадження основного капіталу підприємств реального сектору економіки України у 2014 та 2015 рр. становив 21,8\% та 19,6\%, що свідчить про низхідний інвестиційний тренд та скорочення інвестиційного потенціалу економіки. Одночасне збільшення частки прибутку у доданій вартості у 2015 р. на 8,7 в. п. до 47,3\%, порівняно 32014 р., свідчить про спрямування власних ресурсів не на інвестиціi, а на покриття фінансових втрат, виведення ресурсів за межі країни. Для відновлення висхідного інвестиційного тренду має бути збільшено пропозицію інвестиційних проектів 3 низьким рівнем інвестиційного ризику та високою доходністю і прибутковістю.

Перспективами подальших розвідок мають бути уточнення методичного забезпечення статистики інвестицій, зокрема оцінювання інвестиційного потенціалу.

\section{Список використаних джерел}

1. World Investment Report (2016) "Investor Nationality: Policy Challenges". United Nations Publication. URL: http://unctad.org/en/PublicationsLibrary/wir2016_en.pdf

2. Інноваційна Україна 2020: національна доповідь / За заг. ред. В. М. Гейця та ін.; НАН У країни. Київ, 2015. 336 с.

3. Крючкова I. В. Макроструктурний дизайн економік України та країн OECP // Економіка і прогнозування. 2016. № 3. С. 7-28.

4. Perez C. Innovation systems and policy: not only for the rich? [Electronic resource] URL: http://www.carlotaperez.org/indexofpapers1.html

5. Луніна І. О., Білоусова О. С., Булана О. О. Бюджетно-податкове стимулювання інноваційної діяльності в Україні // Економіка і прогнозування. 2016. № 1. С. 41-56.

6. Онишко С. В. Фінансове забезпечення інноваційного розвитку: моногр. Ірпінь: Національна академія ДПС України, 2004. 434 с.

7. Бережна I. Ю. Особливості формування інвестиційного потенціалу у трансформаційній економіці: інституційний підхід // Ефективна економіка. 2012. № 11. URL: http://www.economy.nayka.com.ua/?op $=1 \& z=1528$

8. Вознюк М. А., Дурицька Г. В. Концепція, сучасний стан і тенденції розвитку інвестиційного потенціалу енергозбереження // Вісник Університету банківської справи Національного банку України. 2014. № 2. С. 102-107.

9. Гавриш В. П., Гулько Л. Г., Драганова Т. П. Методичні основи формування інвестиційного потенціалу підприємства [Електронний ресурc]. URL: http://www. confcontact.com $/ 20101008 / 5$ gavrish.htm

10. Гудзь О. С. Ідентифікація та управління інноваційно-інвестиційним потенщіалом підприємства // Науковий вісник Мукачівського державного університету. Серія: Економіка. 2015. Вип. 2(4). Ч. 1. URL: http://www.msu.edu.ua/visn/wp-content/ uploads/2015/11/2-4-1-2015-17.pdf

11. Дідух С. М. Теоретико-методологічні основи інвестиційного потенціалу підприємства // Економіка: проблеми теорії та практики: Збірник наукових праць. Дніпропетровськ: ДНУ, 2008. Вип. 237: В 6 т. Т. 5. С. 1244-1252.

12. Дресвянніков Д. О. Формування інвестиційного потенціалу підприємства// Вісник Приазовського державного технічного університету. Серія: Економічні науки. 2016. Вип. 31(2). С. 20-27. 
13. Заїка С. О. Інвестиційний потенціал підприємства та варіанти його формування // Науковий вісник Херсонського державного університету. 2015. Вип. 13. Ч. 1. URL: http://www.ej.kherson.ua/journal/economic_13/19.pdf

14. Здреник В. С. Інвестиційний потенціал: сутність поняття та проблеми оцінки // Науковий вісник Ужгородського університету. Серія: Економіка. 2016. Вип. 1(1). C. 363-367. URL: http://nbuv.gov.ua/UJRN/Nvuuec_2016_1(1)_61.

15. Калініченко 3. Методика оцінки інвестиційного потенціалу інтегрованих підприємств // Економічний аналіз. 2010. Вип. 7. С. 273-276.

16. Колтунович О. С. Механізми нарощення інвестиційного потенціалу інноваційнотехнологічної модернізації окремих секторів економіки України // Економічний аналіз: зб. наук. праць / Тернопільський національний економічний університет, Тернопіль: Видавничо-поліграфічний центр Тернопільського національного економічного університету "Економічна думка". 2016. Том 26. № 1. С. 28-31.

17. Чорна М. В., Жувагіна I. О., Горіцин Д. О. Принципи оцінки інвестиційного потенціалу підприємства роздрібної торгівлі // Економічна стратегія і перспективи розвитку сфери торгівлі та послуг. 2014. Вип. 1. С. 87-96.

18. Шабатура Т. Формування інвестиційного потенціалу підприємства в контексті вирішення економічних конфліктів // Проблеми і перспективи економіки та управління, 2016. № 1. С. 235-241.

19. Шамота Г. М. Особливості інвестиційного потенціалу України на сучасному етапі розвитку економіки // Ефективна економіка. 2015. № 11. URL: http://www.economy. nayka.com.ua/pdf/11_2015/26.pdf.

20. Щербатюк O. М. Дефініція “інвестиційний потенціал підприємства": сутність та відмінності / Електронне наукове фахове видання "Ефективна економіка". URL: $\mathrm{http}: / /$ www.economy.nayka.com $. u a / ? \mathrm{op}=1 \& z=773$

21. Zhulavskyi A., Gordiienko V., Samofalova O. Investment Potential of the Enterprise: Theory and Practice of Assessment // Вісник Сумського державного університету. Серія: Економіка. 2015. № 2. С. 7-15.

22. Скриль В. В., Дяченко О. М. Фактори впливу на інвестиційний потенціал промислових підприсмств (на прикладі ПАТ “Полтавакондитер") // Науковий вісник Ужгородського університету. Серія: Економіка. 2014. Вип. 1(42). С. 38-43.

23. Leythienne D., Smokova T. Business profit share and investment rate higher in the EU than in the USA [Electronic resource]. URL: http://ec.europa.eu/eurostat/ documents/3433488/5280941/KS-SF-09-028-EN.PDF/84273e80-a461-479a-958b$37216 \mathrm{~b}$ lbde 30 ?version $=1.0$

24. Eurostat. URL: http://ec.europa.eu/eurostat/tgm/refreshTableAction. do;jsessionid=LamfjjQ_Q1vfkRJA_5jv9FwXOIMuEhb6Houy-IN5q4Pt54Ie1oeb!9961 57364 ?tab $=$ table\&plugin $=1 \&$ pcode $=$ teina5 15 \&language $=$ en .

25. Eurostat. News release Euroindicators. No 62/2017 (12 April 2017). URL: http://appsso. eurostat.ec.europa.eu

26. Investment Brainteaser. Monthly Investment Outlook from Bill Gross [Electronic resource]. URL: https://www.janus.com/insights/bill-gross-investment-outlook

27. Mazzucato $M$. The Entrepreneurial State: debunking public vs. private sector myths (Anthem 2013) [Electronic resource]. URL: http://marianamazzucato.com/

28. Tetlow G., Giles Ch. Economists gloomy on UK prospects for 2017 / Financial Times [Electronic resource]. URL: https://www.ft.com/content/a0c3fce4-d0e2-11e6-b06b$680 \mathrm{c} 49 \mathrm{~b} 4 \mathrm{~b} 4 \mathrm{c} 0$

29. Why is world trade growth slowing? // The Economist. URL: http://www.economist. com/blogs/economist-explains/2016/10/economist-explains-5

30. Marsh \& McLennan Companies. 2017 AFP Risk Survey / Report of survey results (January 2017) [Electronic resource]. URL: https://www.mmc.com/content/dam/mmc-web/ Global-Risk-Center/Files/2017-afp-risk-survey.pdf 
E. С. БЕЛОУСОВА,

кандидат экономических наук, стариий научный сотрудник отдела государственных финансов, ГУ «Институт экономики и прогнозирования НАН Украины»»

\section{Инвестиционный потенциал экономики Украины и стран ЕС}

B статье раскрыта суцность инвестиционного потенциала экономики, ресурсного и затратного подходов кего очениванию. Проанализированы статистические показатели, отражаючие инвестиџионный потенциал в странах ЕС и Украине (уровень накопления основного капитала сектором нефинансовых корпораций, доля прибыли сектора нефинансовых корпораций). Разработаны предложения по совериенствованию системы показателей статистики инвестииий.

Ключевые слова: инвестиции, инвестиционный тренд, инвестиционный потенизиал, риск инвестирования, прибыль.

O. S. BILOUSOVA,

$P h D$ (Economics), Senior Researcher,

Department of Public Finance, Institute of Economics and Forecasting of the NAS Ukraine

\section{The Investment Capacities of the Ukrainian Economy the EU countries}

The article deals with selected aspects of investment in the context of the enhanced competition at investment markets and the need to increase the investment performance. $A$ review of literary sources shows that investment capacities essentially refer to the economy's capability to fund processes or phases related with generation of innovation, formation and modernization of fixed assets or intangible assets; development of education, research and information sectors; reproduction, support and creation of national wealth. It is emphasized that formation and realization of investment capacities in the economy can be attributed to processes that have significant effects for economic performance in the long run, especially when the capacities are innovative. The author's definition of investment capacities of the economy is given, as the capacity to support financially the upward investment trend through accumulating fixed capital and increasing the profit rate from its generation in current and medium-term periods.

The existing methodology for assessment of investment capacities at country level is analyzed; recommendations to improve the system of aggregated investment statistics, taking into account the Eurostat methodology, are given. Statistical indicators measuring the investment capacities in EU countries and Ukraine are analyzed. The analysis shows that the investment rate in Ukrainian industrial enterprises was $21.8 \%$ in 2014 and $19.6 \%$ in 2015, giving an indication of downward investment trend and the shrinking investment capacities of the national economy. Growth in the share of profit in the value added in 2015 by 6.7 percentage points (to 47.3\%) compared with 2014 is evidence that instead of investing internal resources, enterprises use them to cover financial loses or tend to take them off the national boundaries. Upward investment trend can be recovered by the increased supply of investment projects with low level of investment risk and high return and profit rate.

Keywords: investment, investment trend, investment capacities, investment risk, profit.

Посилання на статтю

Білоусова О. С. Інвестиційний потенціал економіки України та країн СС // Науковий вісник Національної академії статистики, обліку та аудиту: зб. наук. праць. 2017. №1-2. С. 60-67. 